\title{
Wolio's Oral Literary Form the Character of Millennial in Buton Islands
}

\author{
Nadir La Djamudi ${ }^{*}$, Asrul Nazar ${ }^{1}$, Kosilah $^{1}$ \\ ${ }^{1}$ Universitas Muhammadiyah Buton, Baubau, Indonesia \\ "Corresponding author. Email: nadirladjamudi@ gmail.com
}

\begin{abstract}
One of the cultural diversities of the Indonesian people is oral literature. Noble values in Oral Literature should contribute to shaping the millennial generation to reinternalize Pancasila's character. The condition of the current millennial generation has been fragile due to the threat of globalization. One practical method of forming the millennial generation is to embody the noble values contained in Wolio Oral Literature in all lines of life. Wolio Oral Literature is a cultural product of the intellectual property of the Butonese ancestors which grew up and developed from generation to generation, delivered orally by the Butonese. The purpose of this study is to describe the noble values in Wolio Oral Literature as an effort to form the character of the millennial generation in Buton Island. The type of this research is descriptive qualitative, which focuses on the depth of appreciation of the interaction between the concepts being studied empirically. The results showed that the noble values forming the characters contained in Wolio Oral Literature are the values of heroism, history, obedience/dedication, perseverance, fortitude, friendship, friendliness (kindness), religious (belief), courtesy, compassion (love dear-love), persistent (hard work), honesty, willing to sacrifice, togetherness, helpfulness, kinship, advice/nurture, and patience. The conclusion of this research is the noble values in Wolio Oral Literature can be a solution to the decadence of the current generation millennial generation character, especially the people in Buton Island.
\end{abstract}

Keywords: literary area, character, millennial

\section{INTRODUCTION}

The country is based on the Republic of Indonesia besides having ethnic diversity also has cultural diversity. Cultural diversity radiates regional language diversity. In the area, there is regional literature created by the supporting community. I studied in language and literature and local culture, there will be a very close association and unity between the three so it is difficult to be pragmatically separated from each other in the framework of life and community life Supporters. In areas that have a successful regional language, maintained by its people, such as Javanese, Sundanese, and Madurese, the language will be respected and maintained by the State also. The languages are also liquid to facilitate the Indonesian culture that lives [1].

Wolio's oral literature, in the Wolio language, has two dimensions of benefit. Firstly, from the language dimension, having the power to unite the narrative, while the second, from the dimension of its valuable content, the speakers can easily recognize the values contained in the oral literary work as Reflection of the public in his day. There is no doubt that a natural-lasting introduction to regional literature will result in a strong cultural deposition for its adherence, in addition to creating an intense sense of unity between regions [2]. Of course, in this connection do not be forgotten its aesthetic values and the value of its ethics contained in the literature.

The importance of the study of values in oral literary works is explained that the element of value in it can be used as one of the guidelines in the construction of daily living, as a companion of the teaching of religious values. The doctrine therein can enrich the inner nation. Such a thing has been put forward at the literary development Seminar that the problems faced by the government today are mental coaching problems. One way is with the passion of literary works, especially old literary works because the literary works reveal the secrets of life that can enrich the human inner. Furthermore, through literary works it can be better loved and better built in the community. From the explanation above it can be concluded that the research or analysis of the values in Wolio's oral literary works is very important. It is intended not only to introduce and to hang literary values to its supporters but also as an effort to preserve the form of oral literature in an effort to enrich national culture. It is common to note that in literary works, including oral literary works, images of national identity in the past. One such identity is the cultural value found in oral literary works. That identity is a mirror of attitude to be exemplary.

The urgency of cultural value studies in oral literary works for the purposes of the disclosure, application, and stability of the nation's cultural values lately is increasingly urgent, not only because the fact that it is increasingly scattered to the back and is often forgotten, but also because of the emergence of a global lifestyle that expands at the end of the XX century [3]. Certainly, the values contained in the oral literary work are very diverse and all have the same status and importance in the lives and lives of the Buton Islands community. 


\section{METHOD}

The study used a qualitative descriptive research design that included a systematic network to obtain answers to proposed problems. Qualitative research is done by not putting the numbers first, but prioritizing the depth of the passion for the interaction between the concepts being examined empirically [4]. This study clearly describes the values contained in oral literary works obtained in available and supporting libraries, so that the research includes descriptive qualitative research and literature. To achieve the accuracy of the data, researchers also gathered the appropriate literature and related to the problems discussed. The study used a qualitative descriptive research design that included a systematic network to obtain answers to proposed problems.

\section{RESULTS AND CONCLUSION}

The presentation of the value findings in each of the above stories has accumulated to know the value of Wolio's literary oral story as the source of this research data. It is certainly obtained as a result of studies or analysis of the folklore structure in question. In understanding the diversity of values contained in the five-folklore studied, we can also group them into two groups. First, a group of material values, classified as material cultures, such as Gong, garden, looking for fish, type of plant, the Sabung/chicken fighting, boat, sailing, looking for fish in the sea, and so on. Second, non-material value groups, such as heroism, history, compliance/ devotion, diligence, steadfastness, material culture, friendship, friendly and good kindness, religious/miracle, affection/affection-loving, persistent/ hard effort, honesty, Willing to sacrifice, togetherness, helpfulness, family, counsel/parenting, moral, patience.

Another grouping way that can make it easier to understand the various content values in the five-folklore studied is according to the proximity of the scope of the meaning of the value found. Therefore, the whole value above can be grouped as follows. (1) culture; (2) Heroism, including willingly sacrificing; (3) historical; (4) Compliance/ devotion, including, courtesy; (5) Diligence encompasses, steadfastness, patience, persistent/hard effort; (6) Friendship, including, togetherness/Senasip-after-death, gracious and good, like to help, honesty; (7) religious; (8) family, including, advice/parenting, affection/affectionloving; (9) Moral.

The development of social culture of society with the increase of human resources seemed very synergistic and inspired by the wisdom of local cultures in the form of Binci principles-Talk Ikikuli (mutual understanding, mutual understanding, tolerance). All the values adopted by the public appear to be undetached and are embraced by religious values. For example, the value of heroism, obedience, courtesy and mutual care and good manners will seem when someone has practiced a poma-masiaka (loving or caring for each other), Popia-Piara (to keep each other), Pomae-Maeaka (embarrassment), and build, lift, motivate, so that the life is harmonious because the essence is Bincitalk ikikuli (tolerance). The three principles of the above value principle, the implicit also the value of friendship, sacrifice, Senasip-after-death, honesty, family, and counsel and diligence.

The development of the social life of the Buton Islands community is based on local religions, customs and culture, meaning to encourage the realization of life based on the sublime values of religion, customs and traditions, and the wisdom of Local that is a reflection of the whole community of Buton Islands, both daily life setting and in the governance of global community. One of the strategies of socio-cultural development, namely the growing local cultural values of Poma-Masiaka, Popia-Piara, PomaeMaeka, and poangka-angkataka, resulting in awareness and criminalization in the form of Binci-binciki Ikikuli, with Vigor: Yindayindamo arataa somanamo karo, Yindaindamo karo somanamo lipu, Yindayindamo lipu somanamo Sara, Yindayindamo Sara Somanamo religion; As an antidote to the outside culture that fits the values of local culture.

So important in preserving the values in question, then the value found in the folklore that researched this need to explain its existence in the life and social life of the Buton Islands community. The content of the values in Wolio oral literature is as follows. The value of heroism, in terms of life, the value of heroism is certainly still preserved and preserved. The first, the value of heroism is manifested in the form of martial arts aimed at, among others to become soldiers of this country. Nowadays, more and more types are pursued in the development effort generation. Logically, we understand that many alternatives can be chosen to realize this patriotism soul by all of us with pragmatic physical and psychic concerns.

Historical value or historic value is still maintained by the Buton Islands community in a physically proven by still maintaining it with the sturdy evidence of the history of Buton Sultanate on the cultural site of the palace of Buton. Although with a different concept. It is said that because of the fact, there are only Buton kingdom and Palace. It was not found the Kingdom and Palace of Wolio. The Kingdom of Buton was Keratonnya in the area of Wolio, which is now in the village of Melai subdistrict Betoambari.

The value of compliance/devotion is constantly implanted to the child in the form of daily coaching. Other than that, it was formally, as in other areas, its implementation was implemented in social institutions, especially in schools, starting at Elementary, Junior, and High school level. It is also commonly started in the next family environment in kindergartens. The importance of this value not only applies to the children, but also to the adult even parents on all walks of life, and on every kind of profession. The farmers, of course, are also very concerned about this obedience. For example, to Parabela (tribal chiefs, who keep a certain area), because if it violates it can result in bad crops for the breaking. For example, pest attack, or crop failure, or other. In general, every citizen's life must be obedient to the setting of the prevailing values of the community. This is where the most conducive moment to instill the main values of Buton culture such as the living philosophy mentioned above. This is where it is necessary to adhere to the courtesy values of all citizens contextually and situational to be good citizens. This diligence value is needed in every area of community social life to succeed in a business or activity. The value of steadfastness is one of the values that should coincide or complement each other with diligence values. If practiced 
both certainly make life easier to understand and can be enjoyed. The concept of the value of obedience/devotion, courtesy, diligence, steadfastness has an essential role in the social life of the society. Some cultural flakes or termed cultural emblems are found in Wolio's oral literature analysis. The epitome of culture is gong, gardening/farming, ketupat, gambling, sailing, boat, martial arts (Manca), Cannon, Castle. In essence the Gong component, still exists, however, its function or usability has shifted. For example, when a boat arrives, no longer uses a gong marker. Gong is still used in certain cultural events for example at the Lariangi dance (from Kaledupa subdistrict), execution events and celebrations of the fiance/marriage. Gardening is still carried out by most communities, especially by communities in certain regions. The type of food or Ketupat cuisine is still loved by the community except that the chicken gambling is almost extinct and no need to defend and be developed again because it is assured of violating religious teachings. Sailing has shifted, because the community considers it more practical to use a motorized boat, no longer using the screen. No more, no, nor produced. Martial Arts (Silat or Manca) are still present in some areas of the Buton Islands.

The value of friendship, friendly and good kindness, affection/affection-loving, honesty. This value is still in Sociyarakat. The value is still being taught to the present generation and is still cultivated and practiced by all members of the community. These values are implied into the main values of Buton culture which was then used as one of the socio-cultural developments and tourism strategy of Baubau City. Baubau city government is teetering to cultivate the values of local culture to defend the identity and characteristics that distinguish it with other areas. The value of local culture in question is; Poma-Masiaka (loving or caring for each other), Popia-Piara (caring for each other), Pomae-Maeaka (embarrassment), and the post (lifting one another), resulting in consciousness and crystallization in form Benches-Discussing Ikikuli (mutual understanding, mutual understanding), with the spirit: Yindayindamo arataa somanamo karo (Let the treasure as long as it is safe), Yindaindamo karo Somanamo lipu (Allow yourself as long as the land is peaceful), Yindayindamo Lipu Somanamo Sara (leave the country as long as customary), and Yindayindamo Sara Somanamo religion (leave customs as long as it is religious). The significance of the value is widespread and deep, aloof throughout this life and nature. By that, the various cultural values above have already covered all the findings of value in the literary work studied. So that the people of the city Bau-Bau is expected to ward off the outside culture that does not conform to the values of local culture.

The religious value found in this study is related to the belief or belief in supernatural and miraculous things. But, in today's life, it has been enmiseren. That is, that babies who are twins with other animals such as crocodiles, octopus, chickens, are not believed by the public. They are more amenable if this is a story or a fairy tale. Some suspect that the fact that the labor of childbirth sometimes forms a variety of patterns, then who sees it, guessing the pattern with the shapes of animals that have been heard through fairy tales. Next, the alleged people who saw the earlier, dissociating a strengthened issue in the affected community with fairy tales. In addition, there are also allegations of biological. That is, they admit that it is sometimes a mother who gave birth to twins. However, the twins have not been perfected the process of the concept so that the fetus is out of various forms. From this form, people are guessing with the form of animals that he often hears through fairy tales. It is certain that until today there has been no real evidence of a twin beast with humans in the Buton Islands community.

Similarly, the story of fish bones planted and grown into bedyl, bullet-leaved, and velvet-leaf trees. There is a wicked giant princess from the moon named Wakinamboro, as well as a beautiful Bidadari, a chicken kukuruyu resembling a human speech, and a beloved eye can be reinstalled. All of them are very difficult to believe. They make sure that such a thing is also not Perna happens, though in ancient times, and it was just a mere fairy tale. Another case with a dream in the community divided the dream into two, namely a dream before midnight and a dream after midnight. If a dream before midnight or before the hour of twelve nights, which is not true. They consider the dream to be caused by imaginary, so it is not true. However, if the dream after midnight or after the hour of twelve nights, it can be true. It is a gesture or a sign of something. About the accuracy or truth of the meaning of his dreams depend people per person. For the sake of this dream, some suggest that we take it or accompany it with dhikr. That is, after setting up the body on the ground, we accompany our wishes with zikir, so that what they want can be seen or real or impaled in a dream

The value is willing to sacrifice and like to help/light the hands, and the togetherness/Senasip-after-death. These three values are in line with the motto of Yindayindamo arataa Somanamo karo (leave the treasure as long as it is safe), Yindaindamo karo Somanamo Lipu (leave the land as long as the land is peaceful), Yindayindamo Lipu Somanamo Sara (Let the country as long as the customary), and Yindayindamo Sara Somanamo religion (leave customs provided religion). Neither the government nor the people have any doubts to cultivate these values in social life as well as in the family sphere. It includes the value of being sacrificed and likes to help and togetherness. This main and sublime value is indeed worth being preserved through the practice for every citizen of the city of Bau-Bau. Willing to sacrifice and light hands, especially with regard to Yindaindamo Karo Somanamo Lipu (let alone as long as the land is peaceful), means willing to sacrifice and light hands for the government. However, it is also implicitly related to one another between the three mottos. another between the three mottos. The value of Senasip-after-death is conducted by the practice of the principle of PomaMasiaka, Popia-Piara, Pomae, and the lift, so that Consciousness and crystallization in the form of a bincibinciki kuli (mutual understanding, mutual understanding). The value of this family is preserved because this is the integrity of a family, whether it is in the relationship of husband to wife, children with parents, children with children, and so forth. On the broader scope of this value can also strengthen harmonious social relationships. The lack of kinship and the thin principle of of Poma-Masiaka, Popia-Piara, Pomae, and the lift of the number of the social 
gaps. The form of social disparities in question, such as riots or other types of split disputes

Literary value. One of the noble obligations among us is to remind each other that the value of this counsel is still held firmly by the Buton Islands community. It is this value that can be relied upon to bequeath the cultural values that are highly proclaimed in the social life of today's society and in the future. This has not only happened in the family sphere, but it is much needed for his practice in the midst of society. Moral value is very difficult to separate from life anywhere, including the social life of the Buton Islands community. Moral is one of the conditions that can be able to invade a person to adopt the above major values. In this case, the meaning is good moral. Even the problem of moral value is not only a concern in society, but it has become a national issue. Proved, everywhere we hear complained of the occurrence of the moral crisis. There are some values in folklore that are capable of reminding us of very reliable moral teachings to answer the crisis. People believe that to resist the unprofitable outside influences and to cook modern life should be based on local customs and culture. In other words, there is a desire to manifest a living ordinance based on the sublime values of religion, customs, and local traditions and wisdom.

\section{REFERENCES}

[1] Undang-Undang Dasar 1945.

[2] Mahmud, Amir, dkk. 1997. Analisis Struktur dan Nilai Budaya. Jakarta: Pusat Pembinaan dan Pengembangan Bahasa, Departemen Pendidikan dan Kebudayaan.

[3] Enre, Fachruddin Ambo. 1992. "Beberapa Nilai Sosial Budaya dalam Ungkapan Sastra Bugis.” Jurnal Pinisi. No. 26. hal 12.

[4] Endraswara, Suwardi. 2003. Metodologi Penelitian Sastra (Epistemologi, Model, Teori, dan Aplikasi). Yogyakarta: Pn. Pustaka Widyatama. 